\title{
Efectos microbiológicos producidos por un evento de surgencia costera en Chile central
}

\author{
Microbiological effects produced by a coastal upwelling \\ off central Chile
}
Juan Kuznar ${ }^{1}$, Juan C. Espinoza' ${ }^{1}$, Sergio Avaria², Mauricio Valenzuela², Camila Pavez ${ }^{1}$ y Miguel Egaña ${ }^{1}$

\author{
${ }^{1}$ Laboratorio de Bioquímica y Virología. Departamento de Química y Bioquímica, Facultad de Ciencias, \\ Universidad de Valparaíso. Gran Bretaña 1111, Valparaíso, Chile \\ ${ }^{2}$ Facultad de Ciencias del Mar y de Recursos Naturales, Universidad de Valparaíso, Valparaíso, \\ Casilla 5080, Reñaca, Viña del Mar, Chile \\ Juan.Kuznar@uv.cl
}

\begin{abstract}
An upwelling is an oceanographic phenomenon which produces a nutrients enrichment of euphotic zones resulting in a phytoplankton bloom crucial for productivity in many coastal zones in Chile. In this research we present information concerning the microbiological effect of an upwelling event. In regard to other studies performed in Chile, we include a novel variable: the changes in virus concentrations in relation with the upwelling and the abundances of phytoplankton and bacterioplankton. The samples were collected at Valparaiso bay (32 ${ }^{\circ} 57^{\prime}$ 's; $71^{\circ} 34^{\prime} \mathrm{W}$ ) during spring 2006. Species composition and high phytoplankton concentrations are according with an upwelling event. After the upwelling, phytoplankton, bacteria and virus increased 24, 6 and 15 times, respectively. Shortly after, phytoplankton and bacterioplankton declined but, in contrast, virus increased 5 more times. This latter is consistent with the idea that virus is important, at least, in the decline of the bacterioplankton concentration.
\end{abstract}

Key words: Nutrient enrichment, phytoplankton, bacteria, virus

\section{Introducción}

La bahía de Valparaíso está influenciada por vientos predominantes del sector S y SW, con alta frecuencia de ocurrencia en primavera y verano, los que generan procesos de surgencia costera que fertilizan la zona eufótica favoreciendo intensas floraciones fitoplanctónicas (Avaria et al. 1989). Los eventos de surgencia que afectan la bahía han sido estudiados por Pizarro (1973), Fonseca (1981), Sievers \& Silva (1979), Prado \& Sievers (1987), Sievers \& Vega (2000) y Silva y Valdenegro (2003) en sus aspectos físicos y químicos, y por Avaria (1975), Alvial \& Avaria (1982), Avaria et al. (1988) y Montecinos \& Balbontín (1993), en sus aspectos
Resumen.- La surgencia es un fenómeno oceanográfico que produce un enriquecimiento de nutrientes de las zonas eufóticas generando un florecimiento del fitoplancton, crucial en la productividad de muchas zonas costeras en Chile. En esta investigación presentamos información respecto al efecto microbiológico de un evento de surgencia. incorporando además de las variaciones en las concentraciones de fitoplancton y bacterioplancton y, como variable novedosa, en relación a otros estudios efectuados en Chile: las variaciones en las concentraciones de virus. Las muestras se obtuvieron en la bahía de Valparaíso (3257’S; 71³4’W) en la primavera de 2006. La composición de especies y las elevadas concentraciones de fitoplancton fueron acordes con la existencia de un evento de surgencia costera. Después de la surgencia el fitoplancton, las bacterias y los virus se incrementaron en 24, 6 y 15 veces, respectivamente. Posteriormente, el fitoplancton y el bacterioplancton decayeron, pero en cambio, los virus aumentaron casi 5 veces más. Esto último es consistente con la idea de que los virus son importantes, al menos, en la disminución de la concentración del bacterioplancton.

Palabras clave: Enriquecimiento nutricional, fitoplancton, bacterias, virus

biológicos. De tales trabajos se concluye que las variaciones del microfitoplancton pueden constituirse en marcadores de un fenómeno de surgencia.

En las zonas de surgencia chilenas se han analizado diferentes aspectos dinámicos de la red trófica considerando al micro, nano y picoplancton. Se ha investigado la relación entre diferentes parámetros hidrográficos con la producción del fitoplancton, bacterioplancton y la productividad primaria (McManus \& Peterson 1988). Asimismo, se ha investigado la predación de nanoheterótrofos sobre bacterias y cianobacterias en aguas con diferente nivel de oxigenación (Cuevas \& Morales 2006). Más recientemente, se 
analizaron las variaciones estacionales del flujo de carbono, considerando, entre otros parámetros, los cambios en la productividad primaria, las biomasas de fitoplancton, protozooplancton y organismos más complejos. Así se logró establecer la importancia relativa de la red trófica microbiana en la transferencia de carbono hacia metazoos omnívoros y carnívoros de gran tamaño (Vargas et al. 2007). Como complemento a estos trabajos es preciso incorporar a los virus como protagonistas en la dinámica trófica marina y su respuesta al estímulo que significan los eventos de surgencia. En las últimas dos décadas se ha establecido que los virus son importantes protagonistas en los ecosistemas marinos con una gran influencia en la composición de sus comunidades.

Millones de partículas virales se pueden encontrar en $1 \mathrm{~mL}$ de agua. Estas provienen, principalmente, de la lisis de las más abundantes formas de vida oceánica, bacterias heterotróficas y fitoplancton (Proctor \& Furhman 1990). Incluso se ha postulado que los virus pueden ser los principales determinantes en la declinación de una floración algal (Suttle 2007). Es por ello que nos parece fundamental estudiar las variaciones cuantitativas de los virus durante el desarrollo de un evento de surgencia y en relación con la temporalidad con que varía la abundancia del fitoplancton.

Solamente existen dos publicaciones en las que se informa respecto de las concentraciones virales que existen en aguas marinas de Chile. En un caso los datos se usan como referencia para comparar con las concentraciones de virus en aguas de lastre (Soto et al. 2005) y en el otro se trata de un registro en la columna de agua asociado a otros parámetros tales como profundidad y abundancia de bacterias (Chiang et al. 2007). Los datos presentados en ambos trabajos son bastante similares. Sin embargo, no existen hasta ahora, registros temporales de la variación de la concentración viral frente a alguna variable hidrográfica vinculada a la estacionalidad. El objetivo de este trabajo fue establecer si los virus, al igual que las bacterias y fitoplancton, son variables importantes en la perturbación biológica que genera un evento de surgencia.

\section{Material y métodos}

\section{Muestreo}

En una estación frente a la bahía de Valparaíso, costa central de Chile (32 $57^{\circ}$ 'S; $71^{\circ} 34^{\prime} \mathrm{W}$ ), se efectuó un muestreo intensivo de microorganismos marinos, desde el 25 de octubre al 1 de diciembre de 2006, con intervalos de uno a cuatro días, obteniéndose 60 muestras de red y agua para análisis taxonómicos de fitoplancton y recuento de células, bacterias y virus (Fig. 1). Para los análisis taxonómicos del microfitoplancton se obtuvieron 30 muestras mediante arrastres horizontales de 15 minutos en superficie, con una red de $62 \mu \mathrm{m}$ de tamaño de malla. Las 30 muestras de agua se obtuvieron también en superficie y con botellas Niskin. Para comprobar la representatividad de las muestras se tomaron, además, muestras de agua a $10 \mathrm{~m}$ de profundidad. La fijación para bacterias y virus se realizó con formaldehído neutralizado al 3\% final y para el fitoplancton se utilizó formaldehído neutralizado al 5\% para las muestras de red, reactivo de Utermöhl (Lugol) para las muestras de agua.

\section{Análisis de microalgas}

El análisis taxonómico se realizó por observación directa al microscopio óptico del material fijado o previamente tratado con $\mathrm{KMNO}_{4}$ al $10 \%$ para la eliminación de materia orgánica de diatomeas e hipoclorito de sodio para la separación de placas en dinoflagelados tecados. La determinación de las especies se hizo en base a literatura especializada y en las reubicaciones taxonómicas se siguió a Hasle \& Syvertsen (1997) y Steidinger \& Tangen (1997).

Los recuentos de células se efectuaron utilizando un microscopio invertido, siguiendo el método de Utermöhl (1958), con las sugerencias propuestas por Avaria (1975). Los resultados se expresan como concentración de células por mililitro (densidad celular). Tanto en el muestreo como en los análisis de laboratorio se tomaron en consideración las recomendaciones pertinentes de Villafañe \& Reid (1995), Franks \& Keafer (2003) y Andersen \& Throndsen (2003). En los cálculos de índices ecológicos se empleó el índice de uniformidad de Pielou y el de diversidad de Shannon-Wiener (Krebs 2001).

\section{Análisis de bacterias}

Las muestras en tubos de poliprolileno de $50 \mathrm{~mL}$ fueron retenidas en filtros de membrana anodisc de $0,2 \mu \mathrm{m}$ de diámetro de poro, los cuales fueron teñidos con Sybr Green I, previamente diluido 1000 veces en agua Milli Q; tras ser mantenidos en oscuridad durante 15 minutos, los filtros fueron lavados con agua Milli Q tres veces y analizados en un microscopio de epifluorescencia para la cuantificación de las bacterias.

Los microorganismos autótrofos fueron analizados desde muestras no tratadas con Sybr Green I y a través de la emisión de fluorescencia roja.

Los filtros conteniendo bacterias $(0,2 \mu \mathrm{m})$ o virus $(0,02 \mu \mathrm{m})$ fueron analizados mediante microscopía de epifluorescencia con aumentos de 400 y $1000 x$ respectivamente. De cada filtro se obtuvieron imágenes RGB de tres campos diferentes y con una resolución de 6 Mpx. Estas imágenes fueron procesadas mediante el 


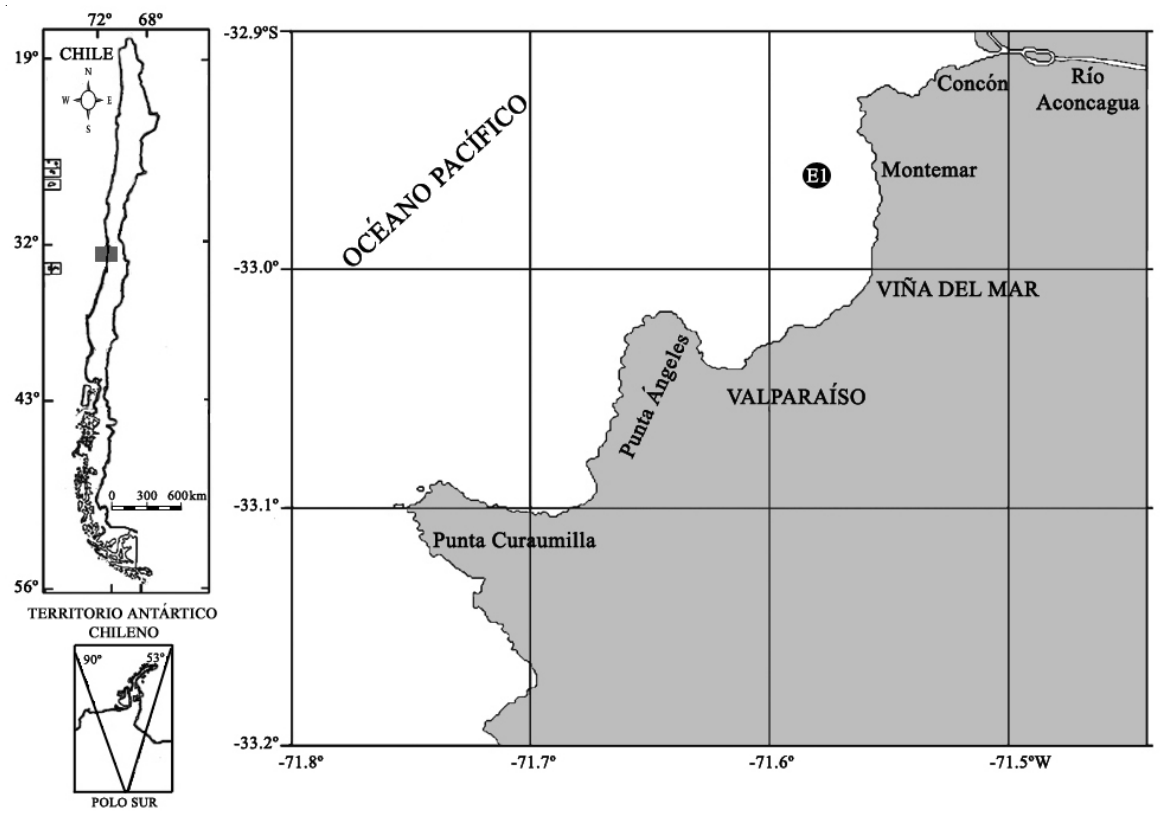

Figura 1

Mapa de la bahía de Valparaíso mostrando la estación donde se tomaron las muestras

Map of Valparaiso bay showing the sampling station

programa Scion Image obtenido gratuitamente desde la página web del National Institute of Health (NIH) de E.U.A. La variación entre los valores numéricos de cada campo no superó el 5\%.

\section{Análisis de partículas virales}

Se filtró $1 \mathrm{~mL}$ de la muestra a través de un filtro dispensable de 0,2 $\mu \mathrm{m}$ de diámetro de poro para eliminar bacterias y otros elementos. La submuestra obtenida, fue nuevamente filtrada en un filtro de membrana anodisc de 0,02 $\mu \mathrm{m}$ de diámetro de poro. En estas condiciones se retuvieron componentes cuyos tamaños oscilaron entre 0,2 y $0,02 \mu \mathrm{m}$; en esta fracción se cuantificaron las partículas virales, que fueron teñidas con Sybr Green I (Noble 2001), diluido 10 veces en agua Milli Q. Tras ser mantenidos en oscuridad durante 15 minutos, los filtros fueron lavados con agua Milli Q tres veces y montados sobre un portaobjetos para observarlos y fotografiarlos mediante un microscopio de epifluorescencia. La variación entre las muestras no superó el 7\%.

\section{Resultados}

Las especies integrantes del microfitoplancton que se distinguieron por su mayor frecuencia y persistencia en las muestras de red fueron las diatomeas, Chaetoceros debilis, Guinardia delicatula, Detonula pumila, Leptocylindrus danicus, Skeletonema costatum, Pseudonitzschia cf. australis y Chaetoceros curvisetus. Los dinoflagelados y silicoflagelados no tuvieron mayor relevancia, debido a su escasa cantidad respecto a las diatomeas.

El análisis cuantitativo de las muestras de agua permitió observar un aumento exponencial de la concentración celular microalgal hacia el 9 de noviembre, el cual alcanzó registros máximos de 2.381 cél. $\mathrm{mL}^{-1}$ (Fig. 2).

Respecto de la abundancia porcentual de las especies que componen el ensamble comunitario fitoplanctónico (Fig. 2), el período de monitoreo se pudo subdividir en tres fases, en función de la estructura comunitaria observada. Durante la primera fase, previa a la proliferación del 9 de noviembre, predominaron las diatomeas del género Chaetoceros, en concentraciones menores de 150 cél. $\mathrm{mL}^{-1}$. Adicionalmente, se registraron bajas concentraciones de Cerataulina pelagica, en malas condiciones fisiológicas, reflejadas en una débil silicificación de los frústulos y pérdida o destrucción de los cloroplastos, la cual es característica de sistemas de mayor estabilidad, sugiriendo que fue la especie dominante en un período de estabilidad previo al pulso máximo de microalgas.

Durante la segunda fase (9 y 10 de noviembre), las diatomeas $G$. delicatula, C. debilis y D. pumila experimentaron un marcado crecimiento exponencial,

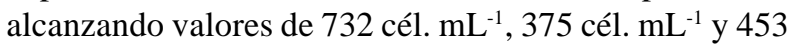




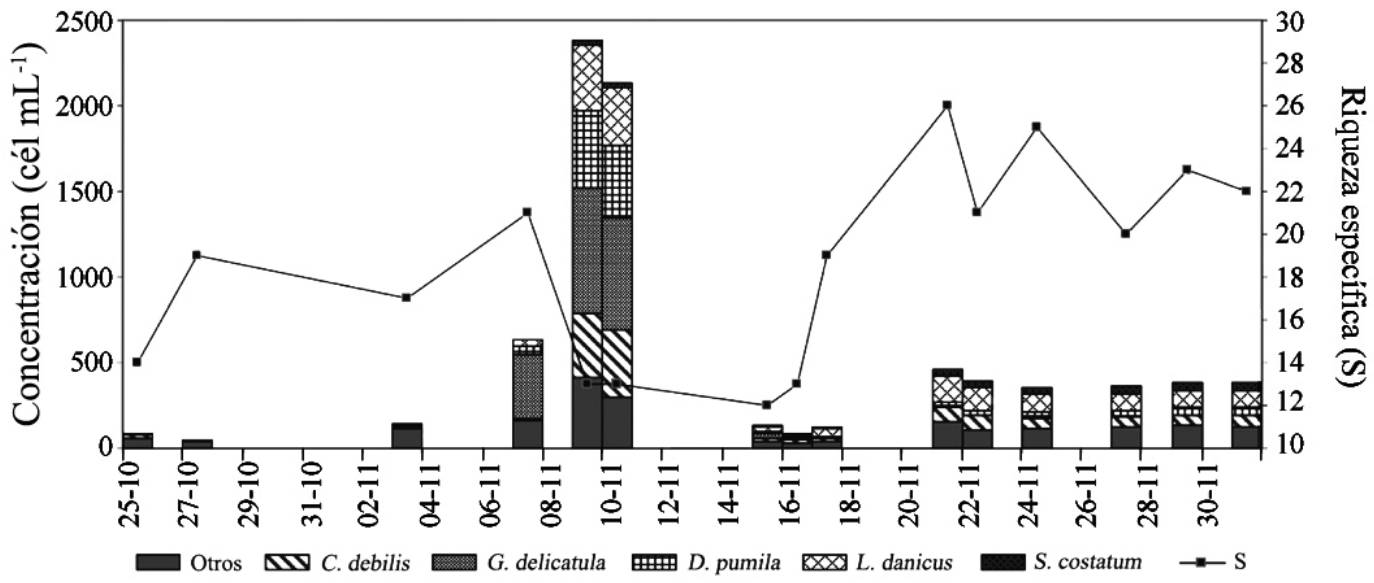

Figura 2

Concentración del microfitoplancton (cél. $\mathrm{mL}^{-1}$ ) y riqueza específica (S) entre el 25 de octubre y 1 de diciembre de 2006. Se destacan los taxa de mayor importancia cuantitativa

Microphytoplankton concentration (cél. $\mathrm{mL}^{-1}$ ) and specific richness (S) between October 25 and December 1, 2006. The taxa with higher quantitative importance are highlighted

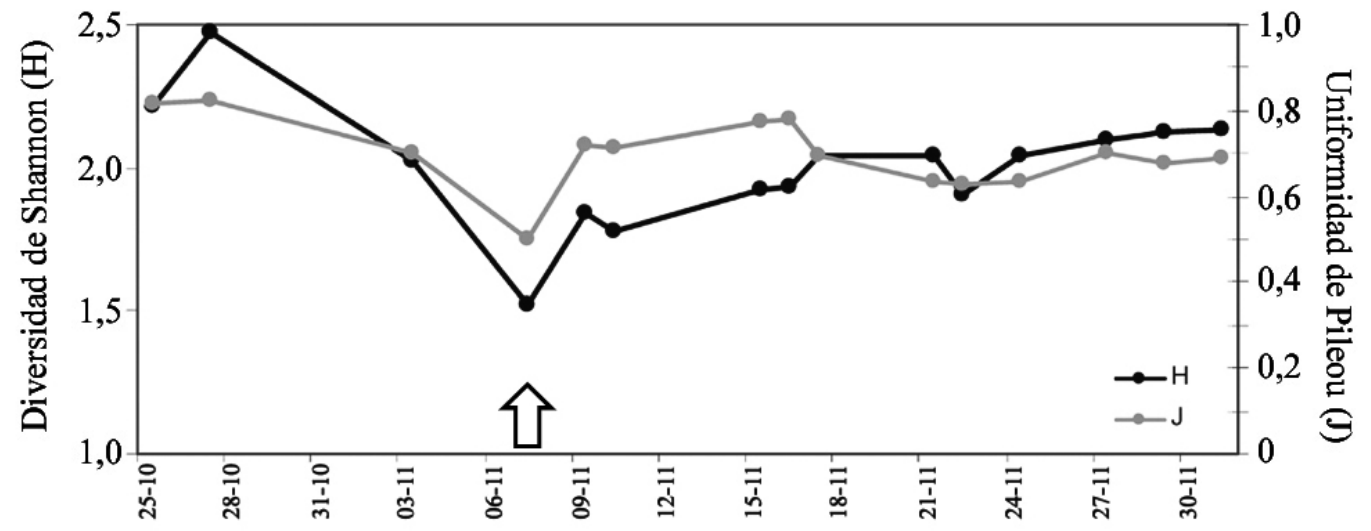

Figura 3

Índices de diversidad de Shannon y de uniformidad de Pielou entre el 25 de octubre y el 1 de diciembre de 2006. La flecha destaca el momento del pulso fitoplanctónico

Shannon diversity index and Pielou uniformity index between October 25 and December 1, 2006. The arrow shows the phytoplankton bloom

cél. $\mathrm{mL}^{-1}$, respectivamente, totalizando el $66 \%$ de la abundancia microfitoplanctónica total. El 16 del mismo mes se registró una disminución de las especies dominantes, y consecuentemente una caída de la concentración total del microfitoplancton, llegando a valores que no superaron las 500 cél. $\mathrm{mL}^{-1}$. En esta tercera fase, de menor abundancia y posterior al 10 de noviembre, se detectó un incremento de la diversidad en directa relación con un cambio en la composición específica de la comunidad, que condujo a la dominancia de C. debilis,
S. costatum, D. pumila y L. danicus, en concentraciones más equitativas respecto del resto de los taxa.

El ensamble comunitario experimentó una alteración evidente en la distribución numérica de las especies que la componen. El 9 de noviembre disminuyeron notoriamente los índices ecológicos estimados, tales como riqueza específica, índice de diversidad de Shannon e índice de uniformidad de Pielou (Fig 3), conjuntamente al aumento de la concentración celular de G. delicatula y C. debilis. Hacia los días 12 y 14 del mismo mes, se 
observó un incremento paulatino de ambos índices, coincidente con el aumento del número de especies (Fig. 2), asociado a la caída en la concentración de los taxa dominantes que se aprecia a partir de 16 de noviembre.

Las concentraciones máximas alcanzadas por las bacterias coincidieron con el máximo de crecimiento del fitoplancton, esto es, el día 9 de noviembre. Posteriormente se produjo una caída aguda en la concentración de las bacterias, la cual se mantuvo durante varios días, a concentraciones algo mayores que las encontradas antes del comienzo de la floración. El día 7, las bacterias alcanzaron un $80 \%$ de su máximo, en cambio, al mismo día, el fitoplancton no superó el 25\% de su valor más alto (Fig. 4). Mayoritariamente se trata de bacterias heterotróficas pues las bacterias autofluorescentes fueron muy escasas, tanto en el día 7 como el 9, en todos los campos ópticos examinados.

Se distinguieron dos períodos en los cuales el número de partículas virales aumentó en relación al momento de la floración del fitoplancton. Uno fue coincidente con la surgencia, días 7 y 9; otro cuyo máximo valor se alcanzó el día 17. Curiosamente, en este último, la concentración de partículas virales fue aproximadamente el doble de la cantidad que se alcanzó el día 7. Es decir, en el momento en que el fitoplancton y las bacterias volvieron a sus valores previos a la floración, los virus presentaron los niveles más altos que se obtuvieron a lo largo de todo el período de muestreo.

En la Tabla 1 se observa que la concentración de células autótrofas eucariontes aumentó 24 veces, la de bacterias, 6 veces y la de virus 15 veces. Estas concentraciones de fitoplancton, bacterias y virus ilustran tres condiciones: la de los días previos, durante y después de la surgencia.

\section{Tabla 1}

Concentraciones de microorganismos antes, durante y después de la surgencia, en los días 3,9 y 17 de noviembre 2006, respectivamente

Microorganism concentrations before, during and after upwelling, corresponding to November 3, 9 and 17,2006 , respectively

\begin{tabular}{rrrr}
\hline & \multicolumn{3}{c}{ Concentración (células o virus $\mathrm{mL}^{-1}$ ) } \\
Día & Microalgas & Bacterias & \multicolumn{1}{c}{ Virus } \\
\hline 3 & $1 \times 10^{2}$ & $1 \times 10^{5}$ & $0,1 \times 10^{7}$ \\
9 & $24 \times 10^{2}$ & $6 \times 10^{5}$ & $1,5 \times 10^{7}$ \\
17 & $0,7 \times 10^{2}$ & $2,5 \times 10^{5}$ & $7 \times 10^{7}$ \\
\hline
\end{tabular}

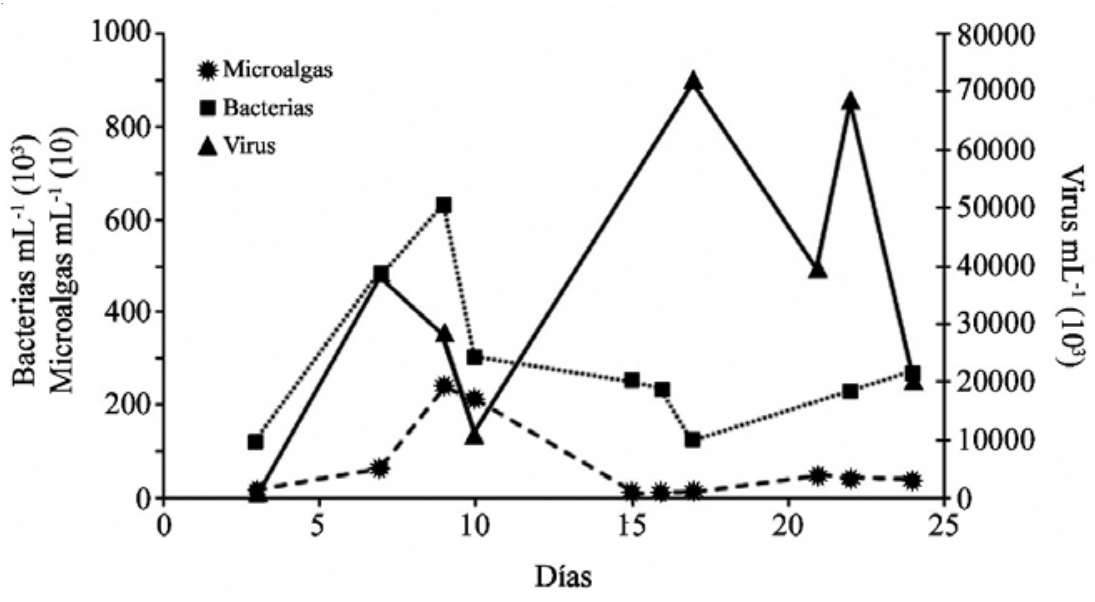

Figura 4

Abundancia de fitoplancton, bacterias y virus en la bahía de Valparaíso

Abundance of phytoplankton, bacteria and viruses in Valparaiso Bay 


\section{Discusión}

Uno de los aspectos centrales de este trabajo es la investigación del orden temporal con que varían diferentes microorganismos en un evento de surgencia. Como era de esperar se observó un orden temporal que estableció claramente una sucesión iniciada con un incremento de los productores primarios concomitante con un aumento en las concentraciones de bacterias heterótrofas. El crecimiento bacteriano se estimula con la materia orgánica liberada por los productores primarios ya sea por lisis, exudación o ruptura parcial de las células de fitoplancton, fenómeno ya descrito (Giovannoni \& Stingl 2005).

El análisis cualitativo permitió observar un importante cambio de las especies dominantes, las cuales experimentaron una transición de diatomeas $k$-estrategas (Guinardia delicatula) a $r$-estrategas (Detonula pumila, Chaetoceros debilis, Leptocylindrus danicus). Este acontecimiento, bajo la teoría de sucesión ecológica, sugiere que, producto de eventuales perturbaciones en las condiciones existentes del sistema costero, se originan nuevas condiciones ambientales, lo que se traduce en nuevas oportunidades para la proliferación de determinadas especies.

La comunidad fitoplanctónica analizada muestra un proceso sucesional en la taxocenosis, en el cual, las especies $r$-estrategas son las que aportan en mayor medida a la abundancia total. Según Margalef (1978), en el ambiente marino, la sucesión de especies es altamente influenciada por los procesos físicos de advección y turbulencia. El mismo autor propuso la sistematización de la morfología funcional del fitoplancton de acuerdo a dos factores ambientales básicos: aporte de nutrientes y la intensidad de la turbulencia. Estudios efectuados en el norte de Chile, revelan que la estructura comunitaria del microfitoplancton está fuertemente acoplada a las fluctuaciones físicas y químicas ocasionadas por la variabilidad de los eventos de surgencia (Santander et al. 2003).

La variación en la concentración celular del microfitoplancton y el tipo de cambio en la estructura comunitaria, en función de los índices ecológicos estimados, sumado al proceso de sucesión observado, permite sostener que la comunidad microfitoplanctónica descrita se encuentra bajo la influencia directa de un fenómeno de surgencia costera acaecido en la primera semana de noviembre.

En los sistemas improductivos la biomasa heterotrófica es más alta que la autotrófica; en cambio, como en el caso de la surgencia, cuando los niveles de nutrientes se incrementan, se produce un cambio progresivo hacia un predominio de los organismos autótrofos sobre los heterótrofos (Gasol et al. 1997, Vargas et al. 2007), situación coherente con lo que hemos observado, las bacterias aumentan 6 veces y los eucariontes autótrofos, 24 veces (Tabla 1 ).

Las concentraciones alcanzadas por los tres tipos de microorganismos en el día de la floración son muy similares a las encontradas por otros autores en circunstancias parecidas: $24 \times 10^{2}$ cél. $\mathrm{mL}^{-1}, 6 \times 10^{5}$ cél. $\mathrm{mL}^{-1}$ y $15 \times 10^{6}$ partículas $\mathrm{mL}^{-1}$ de fitoplancton, bacterias y virus, respectivamente (McManus \& Peterson 1988, Chiang et al. 2007). Comparado con la situación antes de la surgencia, los virus son los que experimentaron el mayor aumento, 70 veces, aunque, varios días después de la floración.

Sorprende que, al menos en parte, el crecimiento bacteriano anteceda a la floración del fitoplancton. La secuencia natural de eventos esperable es que primeramente habría un crecimiento de los productores primarios, y luego, con algún pequeño desfase, se produce el desarrollo bacteriano. Esto no puede explicarse en términos de una importante población de bacterias autótrofas cuyo crecimiento se estimuló por los nutrientes movilizados en la surgencia. Esto debido a que el número de bacterias autofluorescentes siempre fue muy bajo, menos del 2\% (resultados no mostrados).

Es posible que una fracción de la población de bacterias heterótrofas se vea favorecida porque es capaz de respirar algunos sustratos orgánicos arrastrados desde los sedimentos marinos por la surgencia. Dado que las bacterias suelen multiplicarse más rápidamente que las células eucariontes, puede ser que baste que una reducida fracción de la población de microalgas incremente su crecimiento para que aumente explosivamente el crecimiento bacteriano. También es factible que con el apropiado aporte de $\mathrm{N}$ y $\mathrm{P}$, una cierta fracción de las bacterias se desarrolle independientemente de moléculas orgánicas más complejas provistas por el fitoplancton. En experimentos efectuados en lagos se ha demostrado la existencia de este tipo de desacoplamiento (Brett et al. 1999). En general es bastante aceptada la idea de la mutua dependencia del crecimiento bacteriano y del fitoplancton. La lisis de las bacterias proporciona nutrientes para los productores primarios y el fitoplancton proporciona materia orgánica respirable. Por lo tanto, el crecimiento bacteriano debe ser, principalmente, dependiente de la mayor actividad de los productores primarios.

Varias son las causas que pueden explicar el decaimiento tanto de bacterias como microalgas eucariontes. Los nanoflagelados heterótrofos pueden ser los principales consumidores de biomasa bacteriana (Cuevas \& Morales 2006, Vargas et al. 2007); en nuestro caso, no parece ser ésta la principal causa del decaimiento 
bacteriano debido a que las concentraciones de estos organismos son relativamente bajas. Luego, al menos parte del decaimiento bacteriano podría deberse a la lisis producida por la infección viral, lo cual es concordante, a su vez, con el gran aumento de la concentración de virus que se observa concomitantemente con la disminución de la concentración bacteriana.

El decaimiento del fitoplancton, después del 10 de noviembre, puede deberse principalmente a la sedimentación de las células, lisis producida por virus, agotamiento de nutrientes y predación por zooplancton. Los virus tienen gran importancia en el término de las floraciones de fitoplancton, tanto de células eucariontes como procariontes (Brussaard 2004, Suttle 2007). Es difícil explicar el aumento en la abundancia de virus que se observa en la Fig. 4. Es razonable suponer que provienen de las especies cuya concentración decrece acoplada al incremento de la concentración de virus. Sin embargo, para establecer el aporte bacteriano frente al aporte por fitoplancton, habría que analizar la morfología viral. En general, la morfología de los fagos es fácilmente distinguible de la de los virus de origen eucariontes (Suttle 2005). A través de microscopía electrónica podría lograrse una estimación gruesa de la proporción de ambos tipos virales.

Considerando las concentraciones en que se encuentran las bacterias y las microalgas en pleno florecimiento, se pueden hacer algunas consideraciones semi cuantitativas respecto del origen mayoritario de los virus. Aproximadamente cada célula eucarionte tiene la capacidad de producir 10 veces más virus que una célula procarionte. La Tabla 1 muestra que al momento de surgencia la concentración de bacterias fue 250 veces superior a la de las células eucariontes, por lo tanto, es razonable suponer que la mayoría de los virus cuantificados podrían provenir de las bacterias.

Los resultados obtenidos permiten apoyar el concepto que los virus tienen un rol importante en el decaimiento de las concentraciones de bacterias y fitoplancton. Las infecciones virales, con la consecuente lisis de los organismos unicelulares invadidos, son más eficientes en la medida que aumentan las concentraciones de ambos, virus y hospedador, de esta manera aumenta la frecuencia de los encuentros entre virus y célula. De hecho, se ha descrito que cuando se multiplica el número de bacterias por el de los virus y se obtiene un valor de $10^{12}$ o superior, se observa, experimentalmente, una infección lítica (Wilcox \& Fuhrman 1994). En los datos mostrados en la Tabla 1 , se llega a valores superiores a $10^{12}$, tanto durante la surgencia como después de una semana.

Por primera vez en Chile se aporta información que integra las relaciones temporales de abundancias entre fitoplancton (como marcador de un evento de surgencia), bacterias y virus. La información está restringida a la toma de muestras superficiales y en relación a uno solo de tales eventos. Sin embargo, a pesar de ello, emergen relaciones claras entre las abundancias de los microorganismos muestreados relativos al momento en que se produce la surgencia. Sería interesante analizar el patrón que emergerá cuando se obtenga una secuencia de datos que involucre a más de un evento de surgencia y con valores obtenidos día a día.

\section{Agradecimientos}

Proyecto DIPUV 23/2005, Dirección de Investigación y Desarrollo, Universidad de Valparaíso, Centro de Investigación y Gestión de Recursos Naturales (CIGREN), Dirección de Investigación y Desarrollo, Universidad de Valparaíso y a los evaluadores anónimos del manuscrito.

\section{Literatura citada}

Alvial A \& S Avaria. 1982. Proliferación de primavera del fitoplancton en la bahía de Valparaíso. II. Dinámica de las comunidades. Revista de Biología Marina 18: 1-56.

Andersen $\mathbf{P}$ \& $\mathbf{J}$ Throndsen. 2003. Estimating cell numbers. En: Hallegraeff GM, DM Anderson \& AD Cembella (eds). Manual on harmful marine microalgae 4: 99-129. UNESCO Publishing, París.

Avaria S. 1975. Estudio de ecología fitoplanctónica en la bahía de Valparaíso II. Fitoplancton 1970-1971. Revista de Biología Marina 15: 131-148.

Avaria S, P Muñoz \& M Braun. 1988. El fitoplancton frente a la península Los Molles, Valparaíso, Chile (32 $\left.45^{\circ} \mathrm{S}\right)$, y su relación con 'El Niño’ 1982-1983. Revista de Biología Marina 24: 1-35.

Avaria S, S Palma, H Sievers \& N Silva. 1989. Revisión sobre aspectos oceanográficos, físicos, químicos y planctológicos de la bahía de Valparaíso y áreas adyacentes. Biología Pesquera 18: 67-96.

Brett TM, FS Lubnow, M Villar-Argaiz, A Müller-Solger \& CR Goldman. 1999. Nutrient control of bacterioplankton dynamics. Aquatic Ecology 33: 135-145.

Brussaard CPD. 2004. Viral control of phytoplankton populations - a review. Journal of Eukaryotic Microbiology 51: 125-138.

Chiang OE, M Middleboe \& RA Quiñones. 2007. Primer registro de abundancia viral en bahía Coliumo y plataforma central continental frente a Chile central. Gayana 71: 124131.

Cuevas A \& C Morales. 2006. Nanoheterotroph grazing on bacteria and cyanobacteria in oxic and suboxic waters in coastal upwelling areas off northern Chile. Journal of Plankton Research 28: 385-397. 
Fonseca T. 1981. Variabilidad de las corrientes en la bahía de Valparaíso. Investigaciones Marinas 9: 39-60.

Franks PJS \& BA Keafer. 2003. Sampling techniques and strategies for coastal phytoplankton blooms. En: Hallegraeff GM, DM Anderson \& AD Cembella (eds). Manual on harmful marine microalgae 2: 51-76. UNESCO Publishing, París.

Gasol JM, P del Giorgio \& CM Duarte. 1997. Biomass distribution in marine planktonic communities. Limnology and Oceanography 42: 1353-1363.

Giovannoni SJ \& U Stingl. 2005. Molecular diversity and ecology of microbial plankton. Nature 437: 343-348.

Hasle GR \& EE Syvertsen. 1997. Marine diatoms. En: Tomas CR (ed). Identifying marine phytoplankton 2: 5-385. Academic Press, New York.

Krebs C. 2001. Species diversity measures of heterogeneity. En: Cummings B (ed). Ecology, pp. 617-618. Addison Wesley, San Francisco.

Margalef R. 1978. Phytoplankton communities in upwelling areas. The example of NW Africa. Oecologia Aquatica 3: 97-132.

McManus GB \& WT Peterson. 1988. Bacterioplankton production in the nearshore zone during upwelling off central Chile Marine Ecology Progress Series 43: 11-17.

Montecinos A \& F Balbontín. 1993. Índices de surgencia y circulación superficial del mar: implicancias biológicas en un área de de desove de peces entre Los Vilos y Valparaíso, Chile. Revista de Biología Marina 28: 133-150.

Noble TR. 2001. Enumeration of viruses. En: Paul J (ed). Marine microbiology. Methods in microbiology 30: 43-51. Academic Press, New York.

Pizarro M. 1973. Estudios de ecología fitoplanctónica en la bahía de Valparaíso. I. La temperatura superficial y la radiación solar. Revista de Biología Marina 15: 77-105.

Prado R \& HA Sievers. 1987. Distribución de las características físicas y químicas frente a la península de Los Molles, Chile ( $\left.32^{\circ} 45^{\prime} \mathrm{S}\right)$, y su relación con el fenómeno 'El Niño’ 1982/83. Revista de Biología Marina 23: 31-75.
Proctor LM \& JA Fuhrman. 1990. Viral mortality of marine bacteria and cyanobacteria. Nature 343: 60-62.

Santander E, L Herrera \& C Merino. 2003. Fluctuación diaria del fitoplancton en la capa superior del océano durante la primavera de 1997 en el norte de Chile (20¹8'S): II. Composición específica y abundancia celular. Revista de Biología Marina y Oceanografía 38: 13-25.

Sievers H \& N Silva. 1979. Variación temporal de las condiciones oceanográficas frente a Punta Curaumilla, Valparaíso, Chile (mayo de 1974 - abril de 1975). Investigaciones Marinas 7: 3-20.

Sievers H \& S Vega. 2000. Respuesta fisicoquímica de la bahía de Valparaíso a la surgencia generada en Punta Curaumilla y al fenómeno El Niño. Revista de Biología Marina y Oceanografía 35: 153-168.

Silva N \& A Valdenegro. 2003. Evolución de un evento de surgencia frente a punta Curaumilla, Valparaíso. Investigaciones Marinas 31: 73-89.

Soto K, R Durán \& J Kuznar. 2005. Rapid examination of microorganisms in ballast waters. Revista de Biología Marina y Oceanografía 40: 77-82.

Steidinger KA \& K Tangen. 1997. Dinoflagellates. En: Tomas CR (ed). Identifying marine phytoplankton 3: 387-584. Academic Press, New York.

Suttle CA. 2005. Virus at the sea. Nature 237: 356-361.

Suttle CA. 2007. Marine viruses-major players in the global ecosystem. Nature Review on Microbiology 5: 801-812.

Vargas CA, R Martínez, A Cuevas, M Pavez, C Cartes, H González, R Escribano \& G Daneri. 2007. The relative importance of microbial and classical food webs in a highly productive coastal upwelling area. Limnology and Oceanography 52: 1495-1510.

Villafañe V \& F Reid. 1995. Métodos de microscopía para la cuantificación del fitoplancton. En: Alveal K, ME Ferrario, EC Oliveira \& E Sar (eds). Manual de métodos ficológicos, pp. 169-185. Universidad de Concepción, Concepción.

Wilcox RM \& JA Fuhrman. 1994. Bacterial viruses in coastal seawater: lytic rather than lysogenic production. Marine Ecology Progress Series 114: 35-45.

Recibido el 23 de julio de 2008 y aceptado el 22 de enero de 2009 